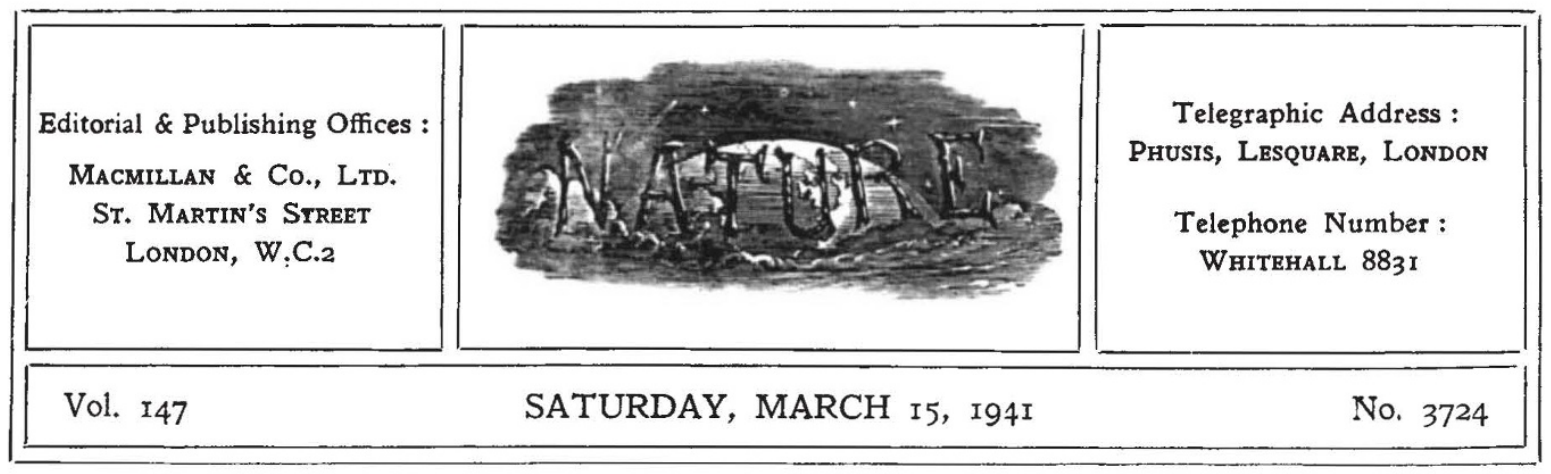

\title{
POPULATION PROBLEMS AND EDUCATIONAL POLICY
}

$\mathrm{U}$ NDER present conditions in the Western World we are faced with a decline in the population which shows every sign of attaining serious dimensions over the coming decades, a decline unparalleled by anything that has happened in human history before. The decline will be most strongly felt in Scandinavian countries, in the white portions of the British Empire, among other nations of Western Europe, and in the United States ; but there is every indication that as time goes on it will extend to all parts of the earth. affecting every race and colour. Opinion may be divided over the immediate causes which have led to the fall in the birth-rate below replacement level. It is significant, however, that it has come about first among those nations which have been foremost in the discovery and application of science. It is significant, too, that the decrease in births has occurred in countries where living standards are higher than elsewhere, so that it can have no relation to the problem of mere survival in any Malthusian sense, and its explanation must be sought in the complex of economic organization and personal ideals which help to make up the present social order.

This decline in the reproduction rate of certain proples is not without its tragedies. In recent years, for example, the Jews in Central Europe have been limiting their births more severely than the nations among whom they have been living. With whatever eyes we may look upon the persecutions and indignities to which they have been subjected, and the efforts made to transport them from one place to another, if left in peace their numbers would have shown a marked falling off even in a generation's time, and the decline might well have been progressive. Similarly, as we watch and take part in the magnificent fight which the British Empire is putting up against the'Totalitarian
Powers, we cannot escape the realization that in a few decades' time, the democratic nations will be considerably weaker in effective man-power than they are now. Victory will have been dearly bought if its fruits sink below a rising tide of superior numbers in other parts of the world. If the British people are to continue as a world power, in any sense of the term, it is imperative that a positive demographic policy should be put into practice, and soon rather than late.

Nor are the problems which a declining birthrate brings upon us restricted to the international field. Great and almost more pressing ones face us at home. It was among the wealthier classes that the practice of family limitation first came to be adopted. This may prove to be a temporary phase ; but while it continues it results in a situation in which the greater part of the next generation is recruited from the lower strata of society, and from those who with the largest families have the greatest struggle to provide the barest essentials of life in the form of food, nursing care and house room. Whether such a state of affairs will lead to any disgenic results, and so produce another type of national decline, is still a moot point. From the pioneer work of M'Gonigle, Orr, and now of many others, it is abundantly clear that the poorer sections of the community, even in normal times of peace, if members of families with several dependants, are cramped in their health and physical development, not to mention those intellectual and cultural influences which civilization should confer. To see that such people receive sufficient for their full physical development would not be an increased burden, but a wise and beneficial investment, which would reveal itself in the improved effectiveness of the nation, whether on the battlefield, in the factory or in the home. Alternatively, the wealthier and professional 
classes, with more house room and easier standards of life, are not reproducing their numbers ; they are not, therefore, bearing their full share in the production of the future British nation, which their higher living standards, their richer cultural environment, and, in some cases at any rate, their superior intellectual endowments should lead us to expect.

Here we are face to face with the crux of the whole problem. At the present time, parents of the wealthier classes have stronger inducements to restrict their families than any other section of the community. They live in an environment in which child-bearing is unpopular, nursing and medical care is expensive; the parent has to see his child through long years at preparatory and public schools, and then at the university, before finally having to produce the capital to see his son launched successfully on a professional or business career. On a proportionate but lower scale the cost of producing and educating daughters is also formidable. While such a state of affairs continues-and it is not easy to visualize any early remedy-the idea of a small family will be extremely difficult to overcome, and since social codes spread from above downwards, it seems likely to affect all grades of society until a considerable amount of social reconstruction has been carried through.

At this stage in the demographic progress of the nation it is interesting but disquieting to observe how acquiescent public opinion and even our intellectual and political leaders are in a situation which, if left to itself, may develop into a national calamity. The reason for this cannot be due to lack of information, for the facts as outlined above have been available for some time past to all readers. The prevailing impression appears to be that some fall in the population of Great Britain would be welcome, and that in the long run things will right themselves. One or two economists have directed attention to the prospects of decreasing markets, and to shifts in consumer demand, but their discussions have borne the impression of being mainly theoretical and of no immediate moment. On the other hand, signs of a change in social emphasis are beginning to appear. The scheme for cheaper milk to children and mothers, under which in certain circumstances it can be provided free, although introduced to alleviate the severity of war-time rationing, is a step in the right direction. A more considerable one would be the introduction of a national scheme of family allow- ances, particularly if its scales were made elastic enough to cover all social grades. Support for the idea of family allowances is growing perceptibly at the present time, but the Government has announced in the House of Lords that the Government cannot find the necessary funds for such a scheme during the War. Curiously enough, opposition to family allowances comes more from the ranks of organized labour, where their effect would be most beneficial, than from those who would have to bear the extra budgetary cost.

So far, the fall in the child population has passed almost unnoticed by health and education authorities, for it has led to concealed, but none the less real, economies in buildings and staff. It has been among the public schools that the fall in recruitment has begun to show itself in the form of actual financial stringency, as well as in empty boarding houses. Among the public schools the decline in numbers has gone so far, having been aggravated by the War, that the Headmasters' Conference has taken the matter up, and the Board of Education is being sounded to see what assistance may be forthcoming from the State. Since discussions are still proceeding it is impossible to forecast what may emerge. Judging from what has appeared in the Press, there are indications that efforts will be made to retain the boarding-school principle, while extending the scope of entry through some form of public assistance.

All such proposals are purely short-range and empirical in character. Although they may contain the seeds of a genuine demographic policy, they are not looked upon in that light by those who have brought them forward. In fact, we have to realize that demographic problems have not yet reached the arena of practical politics anywhere in the British Empire, whether we are thinking of the white people whose numbers are about to decline, or of the coloured races who, under British rule, are multiplying so rapidly that with them Malthusian conditions actually or very nearly apply. Social distress in the West Indies, in India, too, and empty cradles in Great Britain are complementary evidence that to the great majority of our leaders no demographic problem is thought to exist. Such conditions point to the vast field of social welfare and betterment that is waiting to be taken up.

In approaching this field, however, the only line promising any kind of permanent success lies through education, particularly through the application of those biological principles which may be 
termed human biology. What is envisaged is a reorientation of social and personal ideals, so that individualism and money standards no longer hold full sway. The public schools, for example, must come in for a good deal of reconstruction. Founded as most of them were when children were plentiful, and when women in consequence were accorded a low status, they have accentuated the separation of the sexes and imposed a monastic mode of life upon the boys as well as upon the staff. Through their character training they have extolled the ideal of masculine individuality. The leadership principle is the antithesis of co-operative work involving all kinds of people and both sexes. From now on, leadership to be at all effective as a social force must involve responsibility for rather more children than with other grades of society. Such questions as these have been elaborated in greater detail in a memorandum on "Human Biology and the Crisis in the Public Schools"1 issued recently by the Educational Advisory Board of the British Social Hygiene Council. The memorandum merits careful consideration by all who are concerned with the future of the British nation, as well as by those primarily interested in the educational policy of the public schools.

If entry to the public schools is to be widened to maintain numbers, one immediate result may be to intensify the desire in parents to limit their families. To counteract such an influence, in granting its assistance the State should impose conditions calling for reforms in teaching practice and educational aims. For the future it will be necessary to inculcate the idea that girls and

1 Educational Advisory Board, British Social Hygiene Council, Tavistock House South, Tavistock Square, W.C.1. Gratis. women are true partners in life of boys and men, that many of the finest rewards in life, its tenderest emotions and greatest personal satisfactions lie in the home. Sex must be freed from its associations of false sentimentality and furtive pleasures, and made the subject of rational thought and conduct. This should make for greater happiness in providing a more natural framework for human activities and desires, tending to reduce many of the frustrations which now bear so heavily upon society.

In bringing about a new orientation of social standards it is very probable that educational practice will lag behind political expediency, for educational policy is nearly always conservative. The State will have to assume the role of a true parent to its children. To achieve this, the present system of financial rewards in the shape of wages, salaries and profits may need to be modified in keeping with a more co-operative form of community, in which returns bəar a closer relation to the biological responsibilities of individual members. As indicated above, a bold scheme of family allowances would make a big difference. Social and economic rearrangements of this nature would not be in any way subversive, for they would make for a stronger and a healthier nation. They would also provide a bulwark for democracy, for once the principle of family limitation is recognized, the task of bearing children is one of the last that public authorities will ba able to impose upon private individuals. The true source of democracy is the home, and it is from healthy and well-satisfied homes that the future members of the British nation must eventually come.

\section{THE MYSTERY OF RUST}

\section{The Corrosion of Iron and Steel}

Being a General Account of the Work of the Corrosion Committee of the Iron and Steel Institute and the British Iron and Steel Federation. By Dr. J. C. Hudson. Pp. $x v+319+43$ plates. (London: Chapman and Hall, Ltd., 1940.) 18s. net. THE late Sir Robert Hadfield made a hobby of collecting statistics about steel, including the loss caused by corrosion; he mentioned at a time when the world slump was at its height that the destruction due to corrosion that year was probably greater than the total production of new steel. He might well have added, what are we chemists and metallurgists doing about it?

For many years the only remedy was paint: the painting of the Forth Bridge has been described as an eternal circle of operations. When I was a student, G. T. Moody propounded a theory on what happens when iron rusts, which promptly brought forth a rival one from Wyndham Dunstan : engineers were aghast at the temerity of chemists in interfering with the normal happenings of Nature, and were not surprised that the chemists failed to agree. Forty years on, and the bad old times when iron rusted are giving way to the new age of rustless alloys, official committees of investigation, some understanding of the problem, and a considerable amount of first-class research.

It is estimated that the annual cost, including labour, of protecting the iron- and steel-work in 